Gazi University
Journal of Science
http://dergipark.gov.tr/gujs

\title{
Effects of Using New Mold and Modified Secondary Cooling Scenario on Continuous Casting Process at a Steel Plant in Turkey
}

\author{
Emin CELIK ${ }^{(1)}$, Demet ZALAOGLU ${ }^{(1)}$, Emre OZER ${ }^{*}$ \\ Osmaniye Korkut Ata University, Faculty of Engineering, Mechanical Engineering Department, 80000, Osmaniye, Turkey
}

\begin{abstract}
Highlights
- This paper focused on development in the continuous casting process in a steel plant.

- Improvements in the primary cooling and the secondary cooling stages were performed.

- Increased mold life and productivity and reduced the breakouts were obtained.
\end{abstract}

\begin{tabular}{l} 
Article Info \\
\hline \\
Received: $24 / 12 / 2019$ \\
Accepted: $25 / 06 / 2020$ \\
Keywords \\
\hline Continuous casting \\
Steel \\
Billet \\
Mold Design \\
Secondary Cooling
\end{tabular}

\section{INTRODUCTION}

Continuous casting is the dominant process by which almost all liquid steel produced in Basic Oxygen Furnace or Electric Arc Furnace in the world is converted to semi-products namely; blooms, billets, slabs or beam blanks [1-3]. Hence, making improvements in any parts of continuous casting process could lead to important operational benefits via increasing casting speed as well as reducing breakouts and mold wear [3-5]. When liquid steel is poured from tundish into mold, first solidification immediately starts at the inner walls of mold through forming solid shell at outer periphery of strand [4]. The properties of mold influence the heat transfer from strand to cooling water circulating around it very much $[4,6]$. For this reason, a suitable design of parabolic or tapered mold should be required to enhance the heat transfer from strand for the elimination of excessive temperature rise on the outer faces of strand which may cause a considerable decline in the strength and/or ductility of steel and so breakouts during the operation [3,4,7-14]. In designing a mold for continuous casting, the solidification wrinkling of steel and mold distortion should be regarded to define mold inner sizes precisely $[10,11,15]$. This is overly critical to increase the heat transfer rate by preventing gas (mainly air) gap existence between mold and strand [4,7,16-19]. The gas-gap occurrence between strand and mold lowers the heat transfer and this may lead to breakouts in the casting operation which are extremely dangerous [3,4,7,16-19].

In addition to mold properties, the operation parameters in secondary cooling at which the solidification of strand finishes are also very crucial to improve product quality and process speed [3,4,20-25]. Reaching higher casting speeds is possible with suitable mold design and optimization of secondary cooling region [3,4,7,16-25]. Utilization of high casting speeds in continuous casting operations is especially important to enhance productivity via increasing production rate in a steel plant $[11,13,14,26,27]$. Important parameters 
affecting the mold heat transfer at high continuous casting speeds were analyzed and tested by Chow et al. [11]. In addition, the computed mold tapers along mold length were given for low and high carbon steels at various casting speeds at the interval of $3.0-4.5 \mathrm{~m} / \mathrm{min}$ [11]. Casting speed and chemical composition of steel were defined as the most critical parameters influencing the heat transfer from strand through the mold [11]. Samarasekera and Brimacombe [28] examined the defects formed in the continuously cast billets using the mathematical models. The boiling of water at cooling channel of the mold was found to be the primary reason for the formation of these defects [28]. In an extensive study [27], the effects of using oil lubrication and mold powder on the mold heat transfer and the billet quality were given in details. Heard and Kaell [14] studied the casting of various types of carbon steels in a parabolic tapered mold with intensive cooling and different oscillation rates. Higher oscillation with intensive cooling rates in such a mold resulted in the higher casting speeds, i.e. $3.5 \mathrm{~m} / \mathrm{min}$ for low carbon steels and decreased the oscillation mark depths significantly [14]. Florio et al. [7] suggested a thermomechanical model to analyze air-gap formation. They concluded that use of mold taper was very effective in eliminating air-gaps [7]. A parabolic taper mold, designed and used by Fukada et al. and Kyoei Steel Ltd [13], was capable of reaching the high casting speed of $4.6 \mathrm{~m} / \mathrm{min}$ for billet $(130 \times 130 \mathrm{~mm})$ casting [13]. Furthermore, Zhu and Kumar [10] proposed a mathematical model to determine the precise mold taper by considering steel shrinkage, mold distortion, casting speed and steel composition. In order to reach high casting speeds in the continuous casting operations, they offered the mold with a parabolic taper to be used industrially [10]. Moreover, Amitan et al. [9] investigated the shrinkage behavior of various grades of steels containing carbon levels between 0.06 and $0.45 \%$ in the mold for billet casting. They suggested the mold taper values for these steels in billet casting to improve the mold lifetime and product quality [9]. Moreover, they stated that the shrinkage behavior of steel in the mold was mainly determined by the steel composition and the casting speed [9]. Wang et al. [8] made the numerical simulation to derive the shrinkage profiles of different steels along the mold to be able to make the optimization of mold taper. They conducted the simulations on both the round and square billets to analyze the steps of steel shrinkage during its residence in the mold [8]. Finally, they offered suitable tapers for the investigated molds in accordance with the simulation results and implemented them experimentally [8]. In another study, a model based on finite element was developed to get the simulation on thermomechanical behavior steel billets and to make a new mold design for continuous casting process [12]. According to the results of industrial trials, the mold worked well and showed a good performance in terms of product quality [12]. In a more recent study done by Barella et al. [29], the damage mechanisms in the chromium coated copper mold used in the continuous casting operation were determined. The main failure was triggered with the softening of the mold caused by the brass formation due to the zinc diffusion from liquid steel to the copper mold after the break of the coating layer in the mold [29].

In this paper, a new mold with four tapers, which was previously proposed [30], was used at the continuous casting part of a steel factory in Turkey to determine its performance in terms of mold lifetime and product quality in case of casting different types of steels. In the preliminary testing of this new mold in situ [30], it enabled a higher casting speed, namely $4.0 \mathrm{~m} / \mathrm{min}$ during the casting of a low carbon steel (Steel A in Table 2). The main purposes of this study were to increase the mold life and make the quality of billet better for the casting of $150 \mathrm{~mm}$ square billets at the steel plant when casting the steels with different compositions at the high casting speed interval of $3.0-4.0 \mathrm{~m} / \mathrm{min}$. Furthermore, for the steels showing peritectic transition, a reduction in the breakouts and an increment in the casting speed were also targeted. In addition to the use of a new mold, a new cooling scenario at the secondary cooling part was applied to reach these targets. Extensive industrial trials were attempted in this research to determine the lifetime for the new mold during the casting of various structural steels.

\section{EXPERIMENTAL PROCEDURE}

A new copper mold (1000 mm long and Cr-coated) [30] was used in the continuous casting facility at a steel mill in Turkey to determine its performance with respect to important indicators such as casting speed, mold lifetime, product quality and breakouts. The mold inner size which is given in Figure 1 [30], was mainly based on the solidification shrinkage values for low carbon steels [9], mold distortion [15] and mold wear during casting operations at the steel plant. The final taper level for the newly designed mold was changed from $2.6 \%$ at the upper part to $0.65 \%$ at the bottom part [30]. Main details of taper design are given 
in Table 1. The corner radius of the new mold was designed to be $7 \mathrm{~mm}$ to annihilate corner depressions as much as possible. In addition to the utilization of the new mold, a new cooling scenario was adapted and applied to the secondary cooling zone. For this, the arrangement of water sprays with respect to water flux and steps of cooling zones was changed. The new cooling scenario was formed by considering the heat transfer coefficient equation which was suggested by Shimada and Mitsutsuka [31]. The equation [31] is given below:

$h=1.57 W^{0.55}\left(1-0.0075 T_{w}\right)$.

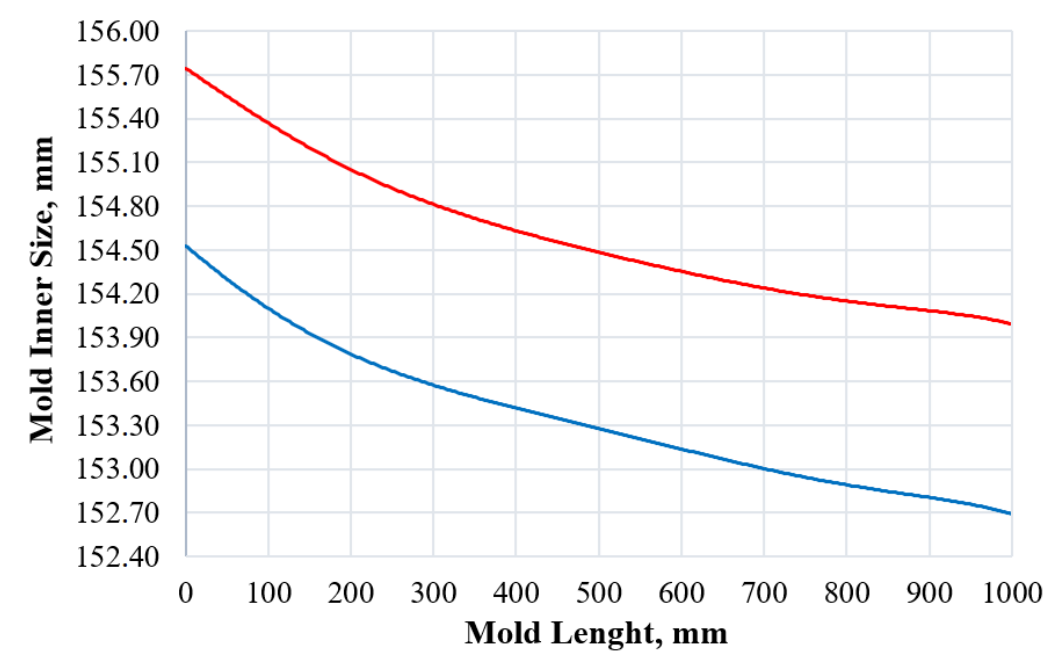

- Old - New

Figure 1. Inner dimensions of the old and new mold versus mold length [30]

Table 1. Taper details of new and old mold [30]

\begin{tabular}{|l|l|c|c|c|c|}
\hline Old & Mold Length (mm) & $0-200$ & $200-450$ & $450-1000$ & - \\
\cline { 2 - 6 } Mold & Taper (\%) & 2.5 & 0.85 & 0.40 & - \\
\hline New & Mold Length (mm) & $0-180$ & $180-550$ & $550-750$ & $750-1000$ \\
\cline { 2 - 6 } Mold & Taper (\%) & 2.6 & 1.04 & 0.78 & 0.65 \\
\hline
\end{tabular}

In this equation, $\mathrm{h}$ is the heat transfer coefficient $\left[\mathrm{kW} / \mathrm{m}^{2} \mathrm{~K}\right], \mathrm{W}$ is water spray flux $\left[1 / \mathrm{m}^{2} \mathrm{~s}\right]$ and $\mathrm{T}_{\mathrm{w}}$ is water temperature $\left[{ }^{\circ} \mathrm{C}\right]$ [31]. The heat transfer coefficient profile was constituted using the above equation [31] by arranging the water spray fluxes to approximate thermal conductivity variation of steel billet throughout the secondary cooling zone [32]. Figure 2 demonstrates the heat transfer coefficient profiles computed by the equation above [31] for the old and new cooling scenarios used at the plant. For the new cooling scenario, the new water spray fluxes were designed and applied at the secondary cooling part where four main zones with different spray fluxes were formed to get closer heat transfer profile. The water spray flux was varied between $32 \mathrm{l} / \mathrm{m}^{2} \mathrm{~s}$ at the first sector and $3.2 \mathrm{l} / \mathrm{m}^{2} \mathrm{~s}$ at the last sector of the secondary cooling zone by arranging the suitable nozzles in seven stages. The water flux level was risen at the top zone of the secondary cooling unit to fasten the heat transfer rate compared to the previous case in the plant. A detailed comparison of the old and new cooling scenarios is given in Table 3.

Table 2. The chemical compositions of steels [wt. \%] cast to determine mold lifetime

\begin{tabular}{|c|c|c|c|c|c|c|}
\hline Steel & C & $\mathrm{Mn}$ & $\mathrm{Si}$ & $\begin{array}{c}\mathrm{P} \\
{[\mathrm{max}]}\end{array}$ & $\underset{[\max ]}{S}$ & $\begin{array}{c}\mathrm{Cu} \\
{[\mathrm{max}]}\end{array}$ \\
\hline A & $0.06-0.08$ & $0.40-0.60$ & $0.15-0.25$ & 0.040 & 0.040 & 0.50 \\
\hline B & $0.07-0.09$ & $0.32-0.50$ & $0.15-0.20$ & 0.025 & 0.025 & 0.35 \\
\hline $\mathrm{C}$ & $0.08-0.12$ & $0.32-0.60$ & $0.15-0.20$ & 0.025 & 0.025 & 0.35 \\
\hline D & $0.15-0.18$ & $0.50-0.70$ & $0.15-0.25$ & 0.040 & 0.040 & 0.50 \\
\hline $\mathrm{E}$ & $0.22-0.25$ & $1.10-1.40$ & $0.15-0.30$ & 0.040 & 0.040 & 0.50 \\
\hline
\end{tabular}




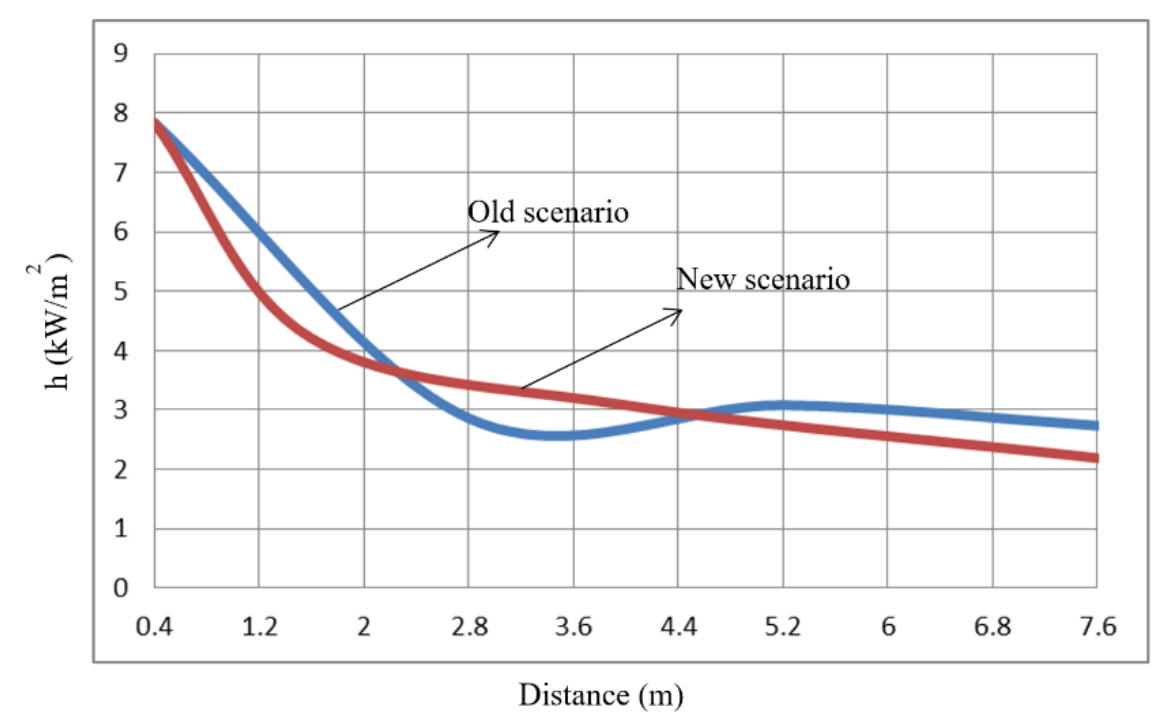

Figure 2. Heat transfer coefficient variation in the secondary cooling zone

Table 3. Comparison of old and new cooling scenario

\begin{tabular}{|c|c|c|c|c|c|c|}
\hline & $\begin{array}{l}\text { Cooling } \\
\text { Section } \\
\end{array}$ & $\begin{array}{l}\text { Cooling } \\
\text { Stage }\end{array}$ & $\begin{array}{l}\text { Length } \\
(\mathrm{m})\end{array}$ & $\begin{array}{c}\text { Water Flow } \\
(1 / \mathrm{s})\end{array}$ & $\begin{array}{c}\text { Nozzle } \\
\text { Type }\end{array}$ & $\begin{array}{c}\text { Number of } \\
\text { Nozzles }\end{array}$ \\
\hline \multirow{7}{*}{ 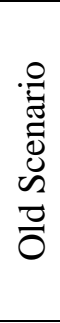 } & Below Mold & Below Mold & 0.4 & 7.75 & 8065 & 40 pc. (5 rows) \\
\hline & \multirow{2}{*}{ Section 1} & Level 1 & 1.2 & 7.50 & 5065 & 48 pc. (12 rows) \\
\hline & & Level 2 & 1.2 & 7.50 & 5065 & 48 pc. (12 rows) \\
\hline & \multirow{2}{*}{ Section 2} & Level 3 & 1.2 & 8.58 & 5065 & 48 pc. (12 rows) \\
\hline & & Level 4 & 1.2 & 8.58 & 3065 & 48 pc. (12 rows) \\
\hline & \multirow{2}{*}{ Section 3} & Level 5 & 1.2 & 6.92 & 3065 & 48 pc. (12 rows) \\
\hline & & Level 6 & 1.2 & 6.92 & 3065 & 48 pc. (12 rows) \\
\hline \multirow{7}{*}{ 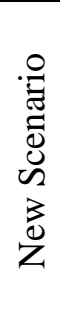 } & Below Mold & Below Mold & 0.4 & 7.75 & 6065 & 40 pc. (5 rows) \\
\hline & Section 1 & Level 1 & 1.2 & 7.50 & 6065 & 48 pc. (12 rows) \\
\hline & \multirow{2}{*}{ Section 2} & Level 2 & 1.2 & 8.58 & 4565 & 48 pc. (12 rows) \\
\hline & & Level 3 & 1.2 & 8.58 & 4565 & 48 pc. (12 rows) \\
\hline & \multirow{3}{*}{ Section 3} & Level 4 & 1.2 & 6.92 & 3065 & 24 pc. (6 rows) \\
\hline & & Level 5 & 1.2 & 6.92 & 3065 & 24 pc. (6 rows) \\
\hline & & Level 6 & 1.2 & 6.92 & 3065 & 24 pc. (6 rows) \\
\hline
\end{tabular}

Numerous industrial trials on site with the new mold and modified secondary cooling zone at the continuous casting machine were sustained to determine the mold lifetime and product quality at the casting speeds changing from 3.0 to $4.0 \mathrm{~m} / \mathrm{min}$ according to the plant's production planning. During the tests in the plant, the operations were made to cast $150 \mathrm{~mm}$ square steel billets with different grades given in Table 2. After transferring the liquid steel from ladle to tundish, its open stream pouring was allowed into the mold to begin the casting operation. Oscillations in the range of 100 to $200 \mathrm{cpm}$ depending on the casting speed and oil lubrication were applied to the mold to avoid the sticking and friction during the casting process. Figure 3 depicts the strands cooled by water jets in the secondary cooling region. In the production procedure, the fully solidified steel billets were cut into suitable lengths for quality control and further manufacturing processes.

After the production of steel billets, the visual examinations were carried out to check the possible formation of defects (cracks, rhomboidity, depressions, breakouts and pinholes) [33,34]. In order to observe the probable subsurface defects (cracks and porosity) as well as grain orientation through the transverse section of the billets, macro-etching of some selected samples was made according to the standard ASTM E340-5 [35] by using the etchant $50 \% \mathrm{HCl}$ and $50 \% \mathrm{H}_{2} \mathrm{O}$ at $70{ }^{\circ} \mathrm{C}$. The microstructural investigations were done after the etching of some selected samples by $2 \%$ nital solution to see grain/phase structure apparently. Olympus BX51 brand light microscope was used in microstructure examinations. The Brinell hardness 
measurements in accordance with the standard ASTM E10-18 [36] were taken on the selected and sliced billet samples to monitor the hardness changes. Hardness measurements of the samples were carried out with Digirock-RBOV brand hardness tester. In the hardness tests, the samples were subjected to a loading of $187.5 \mathrm{~kg}$ with the indenter of $2.5 \mathrm{~mm}$ diameter steel ball. Nine different points throughout the cast billet transversely were evaluated in the measurements as seen in Figure 4.

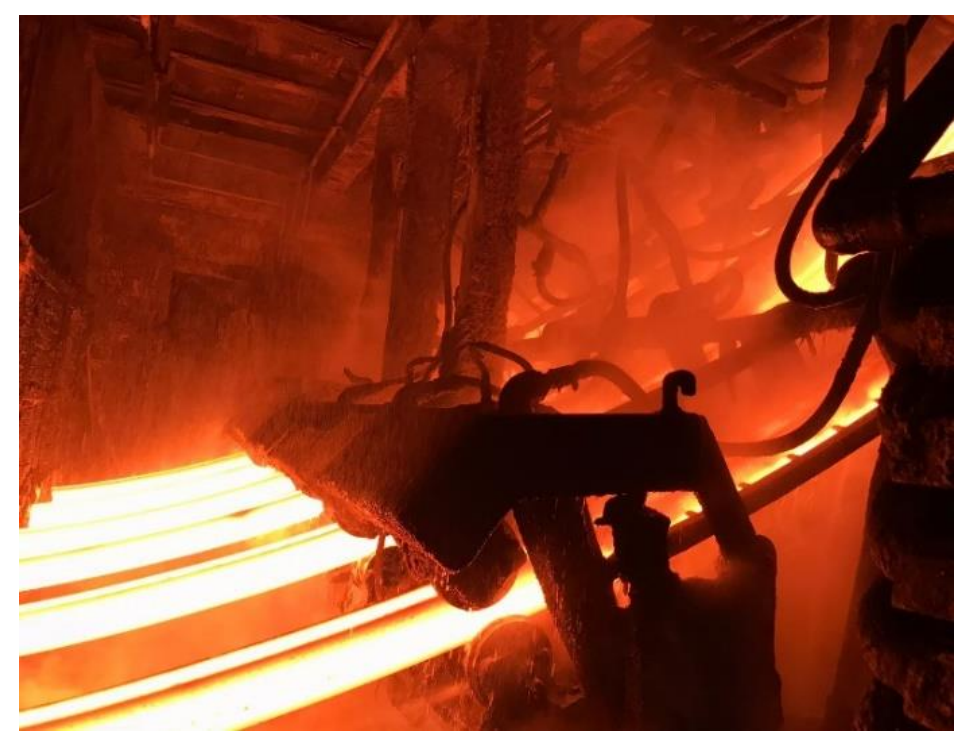

Figure 3. A picture from the secondary cooling zone during the continuous casting

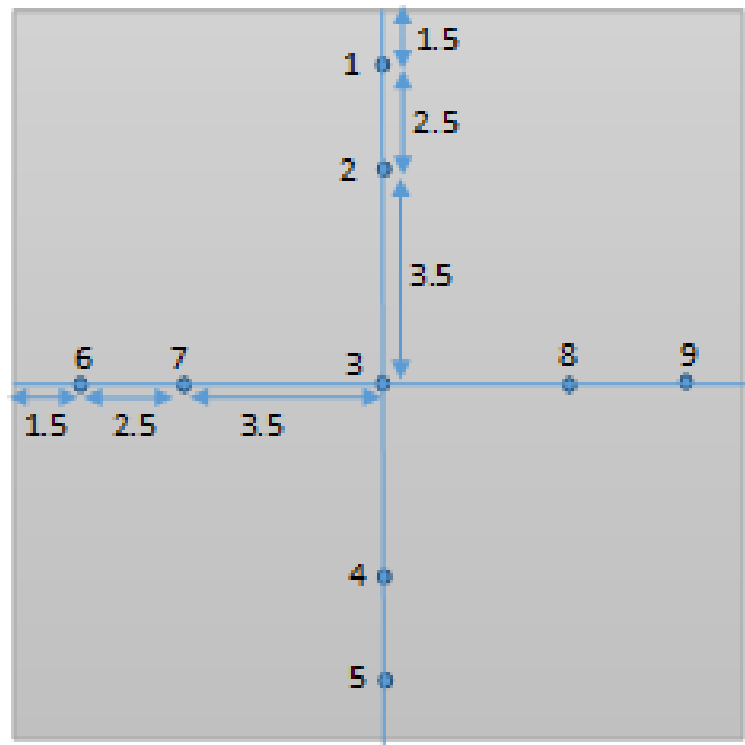

Figure 4. Brinell hardness measurement points (1 to 9) taken on the sliced billet sample transversely. The distances are given in $\mathrm{cm}$ not in scale

\section{RESULTS AND DISCUSSION}

In our previous study [30], the experimental results brought out that the visual examinations for the Steel A with $0.06-0.08 \% \mathrm{C}$ were obtained to be well suited to the plant's requirements as the new mold was utilized at the casting speed of $4 \mathrm{~m} / \mathrm{min}$. In the current research, the visual investigations after the casting of billets at $3.0-4.0 \mathrm{~m} / \mathrm{min}$ exhibited that there were also no cracks detected exceeding the tolerances of the steel factory given in Table 4 for the investigated other steels (Steels B, C, D and E). On the other hand, there were no rhomboidity or depressions observed on the cast samples which mean that the newly used mold and secondary cooling scenario worked well at the process speed of $4 \mathrm{~m} / \mathrm{min}$. The maximum casting speed attained with the old mold in the plant was $3.5 \mathrm{~m} / \mathrm{min}$ [30], and so the improvement in the production rate was also achieved for the steels $\mathrm{B}, \mathrm{C}, \mathrm{D}$ and $\mathrm{E}$ with the new mold and secondary cooling modification. 
Table 4. The tolerances used by the plant for the quality control of billets

\begin{tabular}{|l|c|}
\hline Property & Limit \\
\hline Dimensional Tolerance & $\pm 2 \%$ \\
\cline { 2 - 2 } Rhomboidity & $3 \%$ \\
Deviation from the corner size & (Maximum) \\
\cline { 2 - 2 } Corner depression & $\leq 10 \mathrm{~mm}$ \\
\cline { 2 - 2 } Crack limit & $\leq 3 \mathrm{~mm}$ \\
\cline { 2 - 2 } & $\leq 20 \mathrm{~mm}$ \\
\hline
\end{tabular}

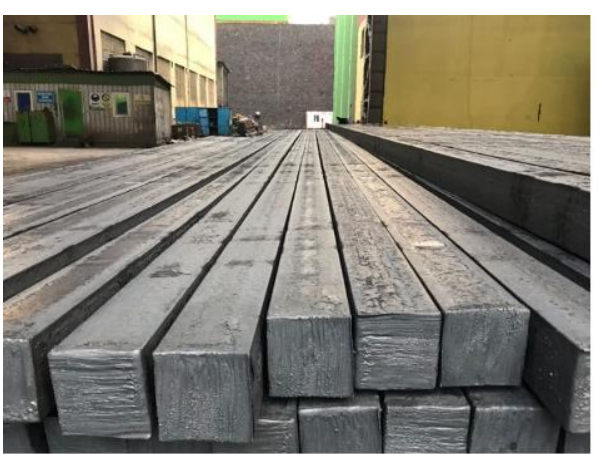

a)

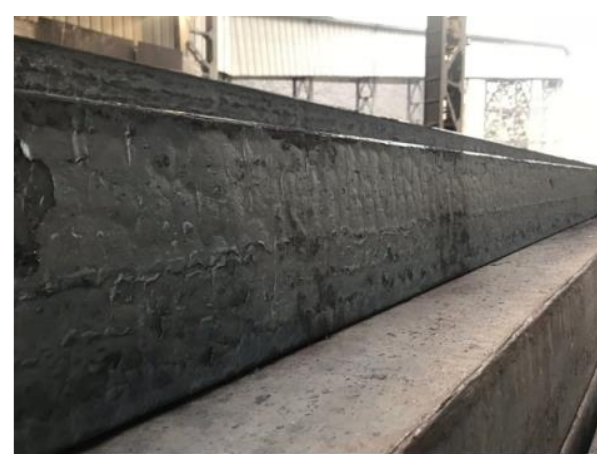

b)

Figure 5. Pictures of some billets cast with the new mold and secondary cooling scenario a) general and b) longitudinal

The rate of heat transfer along the mold is strongly related to the carbon content of the steel $[37,38]$. It diminishes with an increase in the carbon of steel and becomes the lowest for the content of $0.10 \% \mathrm{C}$ $[37,38]$. And then, it starts to increase with a further addition of carbon into steel and remains almost stationary after $0.30 \% \mathrm{C}[37,38]$. The peritectic reaction $(\delta+$ Liquid $\rightarrow \gamma)$ and phase transformation ( $\delta \rightarrow \gamma$ (for hypo-peritectic steels)) are thought to be the main reasons for the reduction of the mold heat transfer in the peritectic composition range since they allow higher shrinkage of steel billet causing more air-gaps formation [3,4,39-42]. This renders the hypo-peritectic steels sensitive to the crack formation [4,39-42]. Among the investigated steels in this research, the Steels C (hypo-peritectic grade), D (near peritectic grade) and $\mathrm{E}$ (hyper-peritectic grade) were cast into square billets successfully within the limits followed by the plant (Table 4). The general and longitudinal views of some steel billets, cast with the new mold and modified secondary cooling scenario, are illustrated in Figure 5. Moreover, Figure 6 represents the cross-sectional pictures of the billet, made of Steel D, that was produced at either 3.0 or $4.0 \mathrm{~m} / \mathrm{min}$.

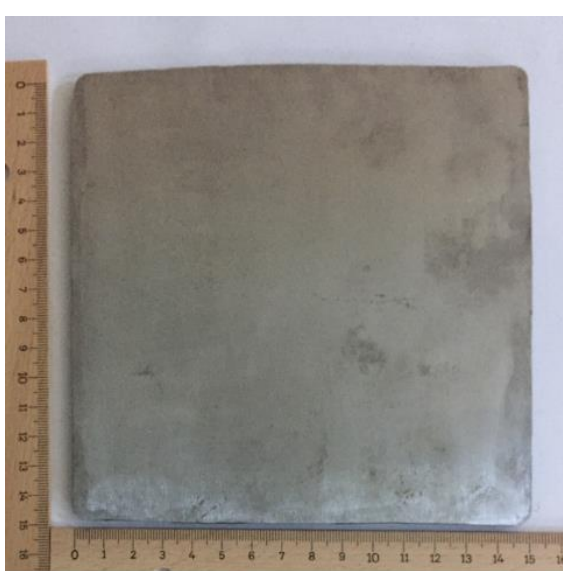

a)

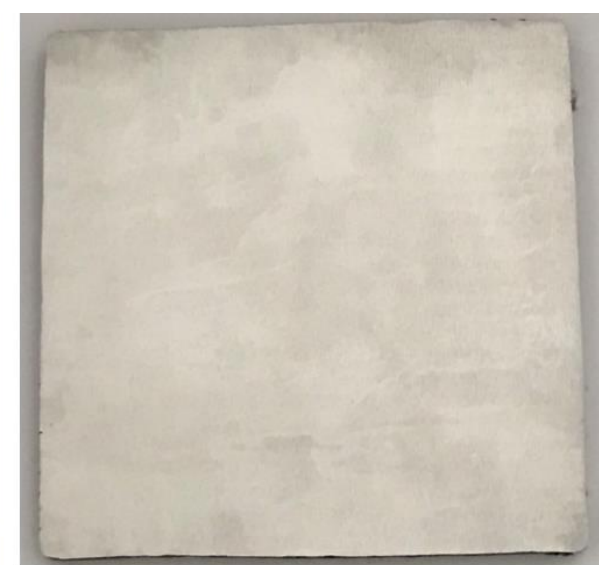

b)

Figure 6. Macro photos of the cross-sectional views of Steel D cast at a) $3.0 \mathrm{~m} / \mathrm{min}$ and b) $4.0 \mathrm{~m} / \mathrm{min}$

Kittaka et al. [43] stated that the casting speeds with the "NS Hyper Mold" were reached 6.0 and $4.6 \mathrm{~m} / \mathrm{min}$ for $130 \mathrm{~mm}$ and $150 \mathrm{~mm}$ square billets, successively. The maximum casting speeds for steel billets were studied by a thermo-mechanical analysis in details [44]. The highest casting speed for 
$150 \mathrm{~mm}$ square steel billets based on bulging criterion was proposed as $\sim 4.5 \mathrm{~m} / \mathrm{min}$ for a mold with $1000 \mathrm{~mm}$ in length [38]. In the current study, the production speed of $4 \mathrm{~m} / \mathrm{min}$, which was attained during the production of $150 \mathrm{~mm}$ square billets, appeared to be high, very productive and near to the theoretical assumption for a $1000 \mathrm{~mm}$ long mold [44].

The macro-etched photos for some selected samples are shown in Figures 7-9. The orientation of columnar grains on heat transfer direction can be observed. While corner depression and convex edge defects are observed in the sample produced with the old mold (Figure 7), these defects are not seen in the samples produced with the new mold (Figures 8 and 9). Only the formation of some gas holes and centerline porosity with some small star type cracks are seen apparently. The formation of gas holes is attributed the entrapping of air into the strand during the open-stream casting. There is no midface, diagonal or corner crack detected in the investigated samples. Typical microstructures of the cast steels are illustrated in Figure 10. The columnar ferritic grains with pearlite islands oriented towards heat transfer direction in the mold are sighted.

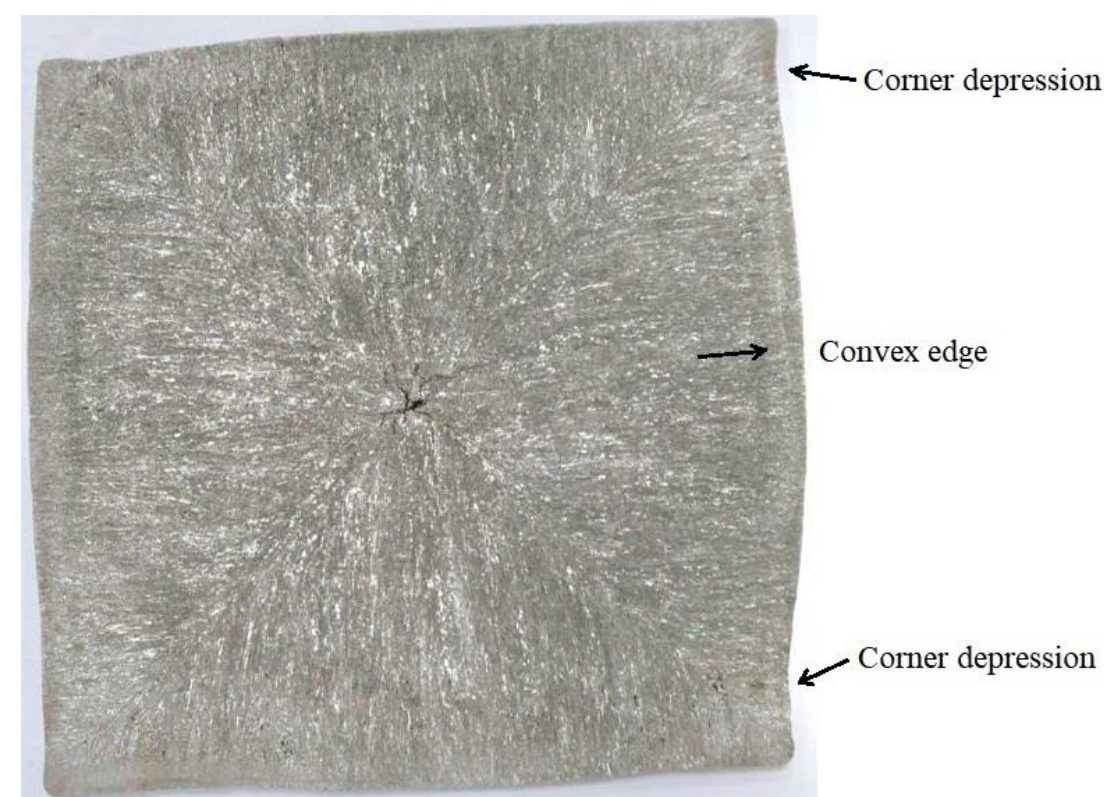

Figure 7. Macro-etched Steel A cast at $3.3 \mathrm{~m} / \mathrm{min}$ with the old mold

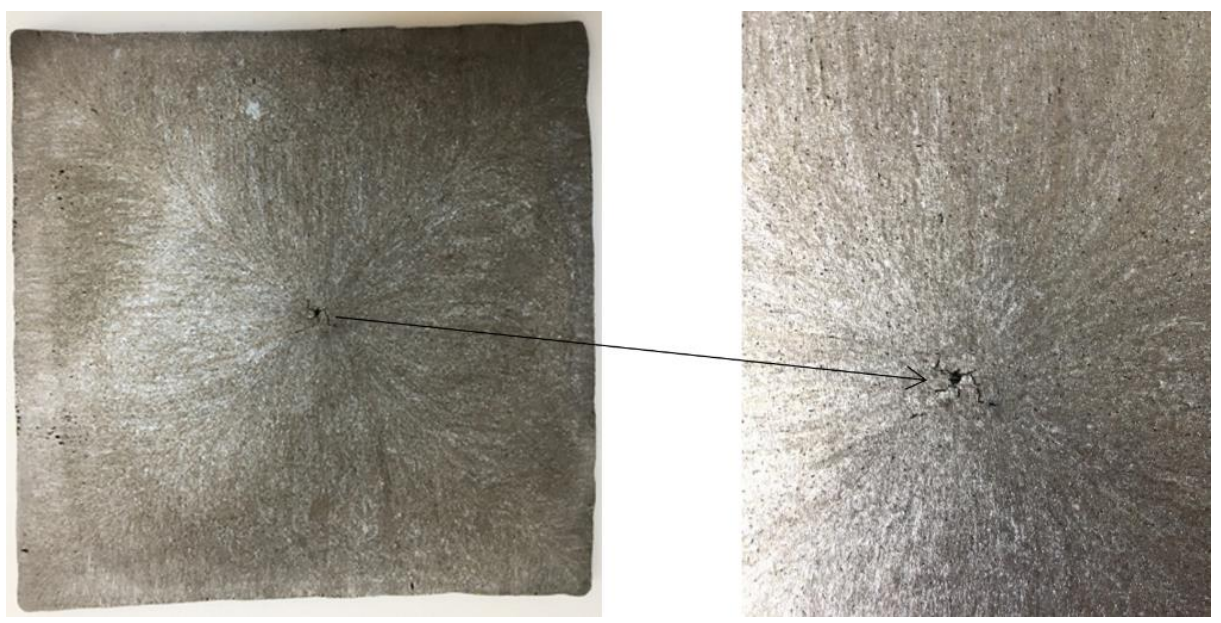

Figure 8. Macro-etched Steel A cast at $3.5 \mathrm{~m} / \mathrm{min}$ with the new mold

The hardness of the samples for the chosen billets in a transverse section are given in Table 5. The general tendency is the hardness drop in the centers of all investigated samples due to the formation of centerline porosity as expected. Even though the hardness level for the steels A, B and C are similar, it becomes higher for the Steel D due to its higher carbon content. 


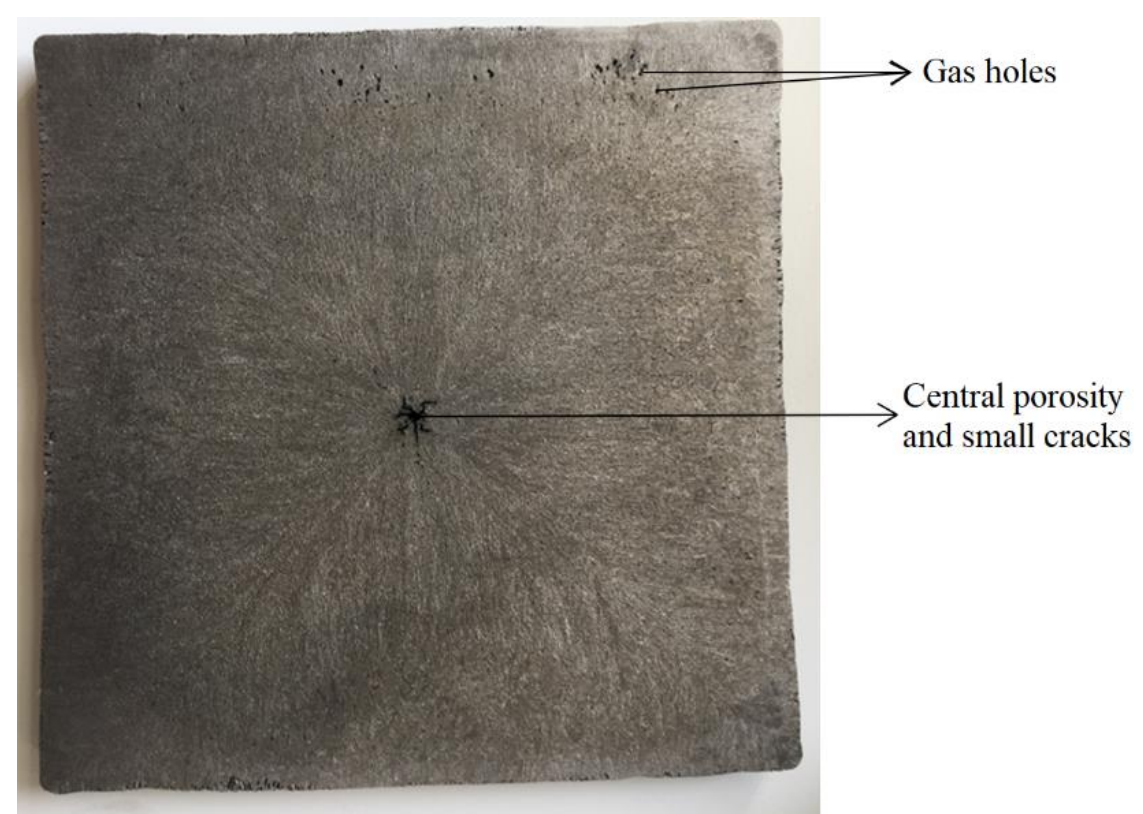

Figure 9. Transverse view of the Steel A cast at $4.0 \mathrm{~m} / \mathrm{min}$ with the new mold after macro-etching

Table 5. Brinell hardness profile of the investigated steel billets depending on the location transversely

\begin{tabular}{|c|c|c|c|c|c|c|c|c|c|c|}
\hline \multirow[t]{2}{*}{ Steel } & \multirow{2}{*}{$\begin{array}{l}\text { Casting } \\
\text { Speed } \\
{[\mathrm{m} / \mathrm{min}]}\end{array}$} & \multicolumn{9}{|c|}{ Points } \\
\hline & & 1 & 2 & 3 & 4 & 5 & 6 & 7 & 8 & 9 \\
\hline A & 3.5 & 121.5 & 121.5 & 99.7 & 119.9 & 121.1 & 133.7 & 133.2 & 129.3 & 130.6 \\
\hline A & 4.0 & 125.5 & 123.1 & 78.8 & 130.2 & 137.4 & 137.4 & 129.8 & 132.4 & 131.5 \\
\hline B & 4.0 & 128.9 & 119.2 & 105.7 & 126.4 & 125.1 & 134.6 & 126.4 & 134.2 & 131.1 \\
\hline $\mathrm{C}$ & 3.0 & 123.9 & 117.3 & 77.9 & 116.1 & 123.5 & 123.9 & 118.4 & 118.4 & 123.5 \\
\hline D & 3.0 & 149.8 & 141.2 & 116.9 & 135.5 & 146.2 & 149.8 & 133.3 & 136.0 & 145.1 \\
\hline D & 3.5 & 149.3 & 141.2 & 80.2 & 143.6 & 150.8 & 149.8 & 141.7 & 145.7 & 148.2 \\
\hline
\end{tabular}

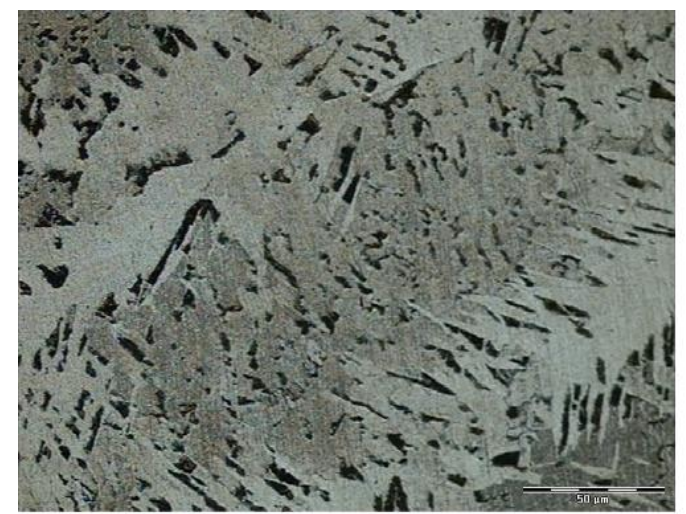

a)

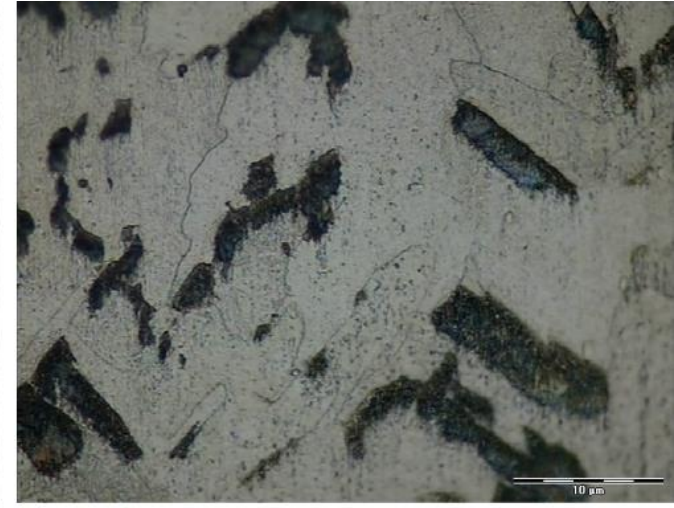

b)

Figure 10. Microstructure of the cast Steel A cast at $4.0 \mathrm{~m} / \mathrm{min}$ with the new mold a) $100 \mathrm{X}$ and b) $500 \mathrm{X}$

Figure 11 demonstrates the mold lifetimes that were found for the investigated molds. For determination of the mold lifetime test, the casting operations were done for the steels given in Table 2 according to the plant's production schedule. Improvements by using the new mold and modification in secondary cooling led to a significant increase in the mold lifetime compared to the old mold. This is due to the fact that the inner size of the new mold is more successful to supply an intimate contact of the mold with the steel billet. Although the replacement of the old mold was necessary after casting $\sim 400$ heats at the casting speeds between 2.5 and $3.5 \mathrm{~m} / \mathrm{min}$, the new mold could withstand the $\sim 650$ heats at the casting speeds of $3.0-$ $4.0 \mathrm{~m} / \mathrm{min}$ corresponding the casting of $\sim 17,000 \mathrm{t}$ steel successfully. Meanwhile, the highest casting speed reached with the old mold was $3.5 \mathrm{~m} / \mathrm{min}$ while the new mold worked at a higher speed of $4 \mathrm{~m} / \mathrm{min}$ 
successfully for the steels B, C, D and E as in the case of casting Steel A billets [30]. The new mold, which was cut longitudinally into two parts after the casting of 654 heats, is depicted in Figure 12. The wear at the bottom part of the mold took place at a great extent since the thicker solid shell formation at the steel strand in this region imposes higher abrasive wear on the mold. In addition, the break of chromium coating on the mold owing to the effect of thermo-mechanical stresses applied by the steel strands is observed clearly. In a previous work, Wang et al. [8] designed and tested a mold having parabolic taper for the round (182 $\mathrm{mm}$ in diameter) and square (165 $\mathrm{mm}$ in size) forms. According to their industrial trials, the lifetime for the round mold was recorded to be 322 heats whereas that for the square one was not mentioned owing to the uncompleted tests [8].

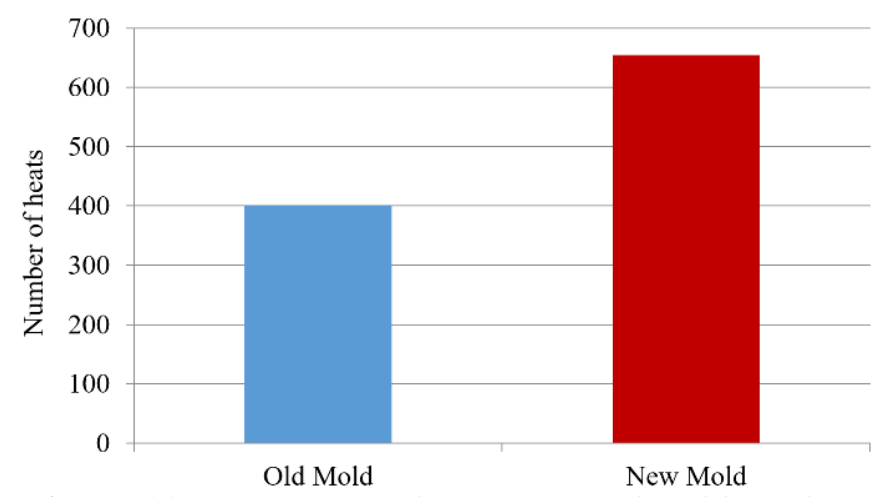

Figure 11. Lifetimes for the investigated molds in this study

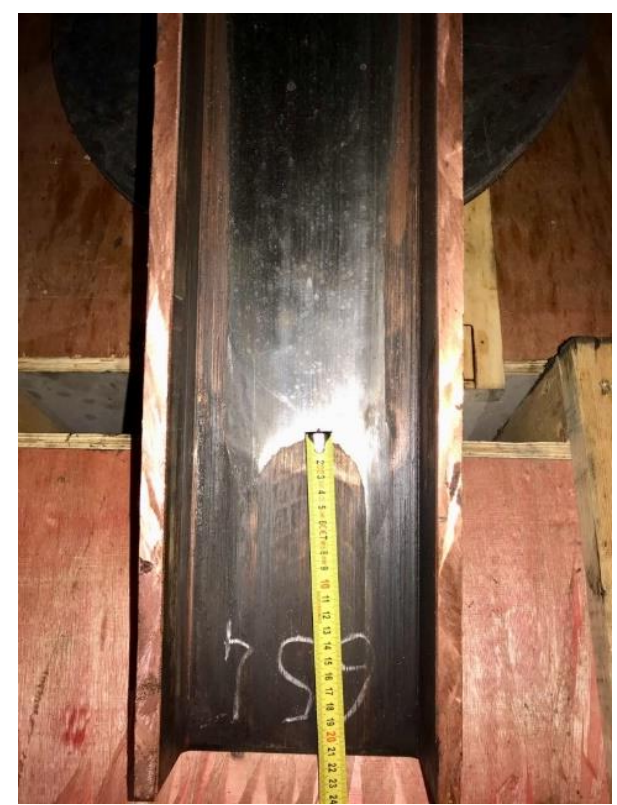

Figure 12. The view of inner wall of the mold after an operation of casting 654 heats

There is a significant difference between heat transfer coefficients of the liquid and solid steel [45]. This makes it necessary to apply the appropriate cooling rate to the primary and secondary cooling zones in the continuous casting process according to the heat transfer coefficients. The heat transfer coefficient obtained by the cooling rate applied in the secondary cooling zone during the continuous casting process has a great effect on surface quality, solidification structure and breakouts [14,46,47]. In addition, there is a direct relationship between the heat transfer coefficient and the distance in the secondary cooling zone [48]. Therefore, the distribution of the cooling method to be applied between the stages directly affects the heat transfer coefficient in the secondary cooling region. Accordingly, the improvements either in primary or secondary cooling zones resulted in the reduction of the breakouts rapidly. Table 6 gives the results of the industrial trials with respect to the breakouts for the casting steels. One of the main issues for the continuously cast billets in the factory, related to the use of the old mold and previous secondary cooling scenario, was the highness of breakouts, approaching 3\% [30]. The main reasons for these high breakouts 
were considered to be related to the lower taper levels of the old mold [30] and insufficient cooling in the section of old secondary cooling procedure between 2.5 and $4.4 \mathrm{~m}$ at which there was a remarkable reduction in the heat transfer coefficient (Figure 2) resulting in higher surface temperatures of the billets.

Upon applying the new mold and secondary cooling scenario for the operation, the breakouts were reduced to $\sim 90 \%$ for short-term total production as shown in Table 6 . The breakouts were reduced to $0.19-0.76 \%$ depending on the steel grade (Table 7) through the changes made in the primary and secondary cooling zones for long-term production. This would cause a significant reduction in the detrimental effects of breakouts with respect to time consumption related to restarting the operation and maintenance and repairing facilities in the continuous casting part during the production. However, reduction in wastage was provided by decreasing breakouts. The production capacity of the factory was increased by increasing the casting speed with the work performed. Increasing casting speed means higher speed in production which comes energy consumption reduction in ladle furnace and tapping as well. In addition to the production speed, an increase in mold life was also achieved. Besides, there was a significant decrease in the number of those who were devoted to second quality in the steels produced, as dimensional defects were reduced.

Table 6. Breakout comparison of the continuous casting for the steels during the industrial trials - short-

\begin{tabular}{|l|c|c|c|c|}
\hline \multirow{3}{*}{ Steel } & \multicolumn{2}{|c|}{$\begin{array}{c}\text { Old mold and } \\
\text { cooling scenario }\end{array}$} & \multicolumn{2}{c|}{$\begin{array}{c}\text { New mold and } \\
\text { cooling scenario }\end{array}$} \\
\cline { 2 - 5 } & $\begin{array}{c}\text { Number } \\
\text { of heats }\end{array}$ & Breakouts & $\begin{array}{c}\text { Number } \\
\text { of heats }\end{array}$ & Breakouts \\
\hline A & 170 & 25 & 184 & 2 \\
\hline B & - & - & 128 & 1 \\
\hline C & 19 & - & - & - \\
\hline D & 221 & 30 & 112 & 2 \\
\hline E & 2 & - & 1 & - \\
\hline Total & 412 & 55 & 425 & 5 \\
\hline
\end{tabular}

Table 7. Breakouts of the continuous casting for the steels during the industrial trials with the new mold and secondary cooling scenario - long-term

\begin{tabular}{|l|c|c|c|}
\hline Steel & $\begin{array}{c}\text { Number } \\
\text { of heats }\end{array}$ & $\begin{array}{c}\text { Total Breakouts } \\
\text { (for 6 molds) }\end{array}$ & $\begin{array}{c}\text { Breakouts } \\
(\%)\end{array}$ \\
\hline A & 672 & 13 & 0.32 \\
\hline B & 735 & 11 & 0.25 \\
\hline C & 432 & 5 & 0.19 \\
\hline D & 636 & 15 & 0.39 \\
\hline E & 44 & 2 & 0.76 \\
\hline Total & 2519 & 46 & 0.30 \\
\hline
\end{tabular}

\section{CONCLUSIONS}

Improvements done in the cooling regions of the continuous casting part at a steel mill in Turkey maintained the substantial revenues given below:

- The mold lifetime was extended by $64 \%$.

- A great reduction $(\sim 90 \%)$ in the breakouts was attained for the investigated steels.

- The productivity was raised by $\sim 16 \%$ due to the rise in the casting speed to $4.0 \mathrm{~m} / \mathrm{min}$ for Steels B, $\mathrm{C}, \mathrm{D}$ and $\mathrm{E}$ as in the case of Steel A [30].

- The new mold is currently used at the steel plant in daily production successfully.

\section{CONFLICTS OF INTEREST}

No conflict of interest was declared by the authors. 


\section{REFERENCES}

[1] Internet: Steel Statistical Yearbook 2017, World Steel Association, Brussels Belgium. https://www.worldsteel.org/en/dam/jcr:3e275c73-6f11-4e7f-a5d8-

23d9bc5c508f/Steel+Statistical+Yearbook+2017.pdf, (2019).

[2] Wolf, M.M., Historical Aspects and Key Technologies, Cramb, A.W. (Ed), Making, Shaping and Treating of Steel: Casting 11th Edition, The AISE Steel Foundation, Pittsburgh, USA, (2003).

[3] Samarasekera, I.V., Chow, C., Continuous Casting of Steel Billets, Cramb, A.W. (Ed), Making, Shaping and Treating of Steel: Casting 11th Edition, The AISE Steel Foundation, Pittsburgh, USA, (2003).

[4] Gilles, H.L., Primary and Secondary Cooling, Cramb, A.W. (Ed), Making, Shaping and Treating of Steel: Casting 11th Edition, The AISE Steel Foundation, Pittsburgh, USA, (2003).

[5] Schade, J.H., O’Malley, R.J., Kemeny, F.I., Sahai, Y., Zacharias, D.J., Tundish Operations, Cramb, A.W. (Ed), Making, Shaping and Treating of Steel: Casting 11th Edition, The AISE Steel Foundation, Pittsburgh, USA, (2003).

[6] Schwerdtfeger, K.J., Heat Withdrawal in Continuous Casting of Steel, Cramb, A.W. (Ed), Making, Shaping and Treating of Steel: Casting 11th Edition, The AISE Steel Foundation, Pittsburgh, USA, (2003).

[7] Florio, B.J., Vynnycky, M., Mitchell, S.L., O’Brien, S.B.G., "On the interactive effects of mould taper and superheat on air gaps in continuous casting", Acta Mech., 228(1): 233-254, (2017).

[8] Wang, T., Cai, S., Li, J., Xu, J., Chen, Z., Zhu, J., Cao, Z., Li, T., "Mould taper optimization for continuous casting steels by numerical simulation”, China Foundry, 7(1): 61-67, (2010).

[9] Amitan, V., Kravtsov, V., Sheludchnko, V., Mass, N., Birukov, A., Kabanets, A., "Development of optimal inner mould shape for high capacity billet continuous casting machines", Metal 2005, Hradec nad Moravicí, Czech Republic, (2005).

[10] Zhu, L-G., Kumar, R.V., "Modelling of steel shrinkage and optimisation of mould taper for high speed continuous casting", Ironmak. Steelmak., 34(1): 76-82, (2007).

[11] Chow, C., Samarasekera, I.V., Walker, B.N., Lockhart, G., "High speed continuous casting of steel billets: Part 2: Mould heat transfer and mould design", Ironmak. Steelmak., 29(1): 61-69, (2002).

[12] Wang, T.M., Cai, S.W., Xu, J., Du, Y.Y., Zhu, J., Xu, J.J., Li, T.J., "Continuous casting mould for square steel billet optimised by solidification shrinkage simulation”, Ironmak. Steelmak., 37(5): 341 $346,(2010)$.

[13] Fukada, N., Marukawa, Y., Abe, K., Ando, T., "Development of mold (HS-MOLD) for high speed casting", Can. Metall. Quart., 38(5): 337-346, (1999).

[14] Heard, R., Kaell, N., "Technological developments for high speed casting of sensitive steel grades", Can. Metall. Quart., 38(5): 331-335, (1999).

[15] Brimacombe, J.K., Samarasekera, I.V., Lait, J.E., Continuous Casting: Heat Flow, Solidification and Crack Growth, Volume 2, The Iron and Steel Society of AIME, Warrendale, USA, (1984).

[16] Li, C., Thomas, B.G., "Ideal taper prediction for billet casting", 2003 ISSTech Steelmaking Conference, Indianapolis, USA, ISS-AIME, Warrendale, PA, 685-700, (2003). 
[17] Florio, B.J., Vynnycky, M., Mitchell, S.L., O'Brien, S.B.G., "Mould-taper asymptotics and air gap formation in continuous casting", Appl. Math. Comput., 268: 1122-1139, (2015).

[18] Samarasekera, I.V., Brimacombe, J.K., “The continuous-casting mould”, Int. Mater. Rev., 23(1): 286300, (1978).

[19] Thomas, B.G., "Modeling of the continuous casting of steel—past, present and future", Metall. Mater. Trans. B, 33(6): 795-812, (2002).

[20] Chaudhuri, S., Singh, R.K., Patwari, K., Majumdar, S., Ray, A.K., Singh, A.K.P., Neogi, N., "Design and implementation of an automated secondary cooling system for the continuous casting of billets", ISA T., 49(1): 121-129, (2010).

[21] Ito, Y., Murai, T., Miki, Y., Mitsuzono, M., Goto, T., "Development of Hard Secondary Cooling by High-pressure Water Spray in Continuous Casting”, ISIJ Int., 51(9): 1454-1460, (2011).

[22] Raudensky, M., Horsky, J., "Secondary cooling in continuous casting and Leidenfrost temperature effects”, Ironmak. Steelmak., 32(2): 159-164, (2005).

[23] Raudensky, M., Tseng, A.A., Horsky, J., Kominek, J., "Recent developments of water and mist spray cooling in continuous casting of steels", Metall. Res. Technol., 113(5): 509, (2016).

[24] Alvarez de Toledo, G., Lainez, J., Cirion, J.C., "Model optimization of continuous casting steel secondary cooling", Mater. Sci. Eng. A, 173(1-2): 287-291, (1993).

[25] Zhao, L., Wang, G., International Conference on Intelligent Control and Computer Application (ICCA 2016), Zhengzhou, China, 146-149, (2016).

[26] Chow, C., Samarasekera, I.V., "High speed continuous casting of steel billets: Part 1: General overview", Ironmak. Steelmak., 29(1): 53-60, (2002).

[27] Samarasekera, I.V., Brimacombe, J.K., "Evolution or Revolution? - A New Era in Billet Casting", Can. Metall. Quart., 38(5): 347-362, (1999).

[28] Samarasekera, I.V., Brimacombe, J.K., "The influence of mold behavior on the production of continuously cast steel billets", Metall. Mater. Trans. B, 13(1): 105-116, (1982).

[29] Barella, S., Gruttadauria, A., Mapelli, C., Mombelli, D., "Investigation of failure and damages on a continuous casting copper mould", Eng. Fail. Anal., 36: 432-438, (2014).

[30] Übeyli, M., Çelik, E., Özer, E., "Improvement of Continuous Casting Operation Using a New MultiTaper Mold at a Steel Plant in Turkey", VIIIth International Metallurgical Congress, Ohrid, Macedonia, (2018).

[31] Shimada, M., Mitsutsuka, M., "On Heat Transfer Coefficient by Forced Water Cooling to Carbon Steel”, Tetsu-to-Hagane, 52(10): 1643-1650, (1966).

[32] Meng, Y., Thomas, B.G., "Heat-transfer and solidification model of continuous slab casting: CON1D", Metall. Mater. Trans. B, 34(5): 685-705, (2003).

[33] Kumar, S., Meech, J.A., Samarasekera, I.V., Brimacombe, J.K., "Knowledge Engineering an Expert System to Troubleshoot Quality Problems in the Continuous Casting of Steel Billets", IFAC Proc., 25(17): 95-102, (1992). 
[34] Emi, T., Surface defects on continuously cast strands, Cramb, A.W. (Ed), Making, Shaping and Treating of Steel: Casting 11th Edition, The AISE Steel Foundation, Pittsburgh, USA, (2003).

[35] ASTM E340-5, Standard practice for macroetching metals and alloys, ASTM International, USA, (2015).

[36] ASTM E10-18, Standard test method for Brinell Hardness of metallic materials, USA, (2018).

[37] Singh, S.N., Blazek, K.E., "Heat transfer and skin formation in a continuous-casting mold as a function of steel carbon content”, JOM-J. Min. Met. Mat. S., 26(10): 17-27, (1974).

[38] Singh, S.N., Blazek, K.E., "Heat-Transfer Profiles in Continuous Casting Mold as a Function of Various Casting Parameters", National Open Hearth and Basic Oxygen Steel Conference Proceedings, ISS-AIME, St. Louis, Mo, USA, 59, 264-283, (1976).

[39] Saeki, T., Ooguchi, S., Mizoguchi, S., Yamamoto, T., Misumi, H., Tsuneoka, A., "Effect of Irregularity in Solidified Shell Thickness on Longitudinal Surface Cracks in CC Slabs", Tetsu-toHagane, 68(13): 1773-1781, (1982).

[40] Vereecke, M., Vermeirsch, W., Meers, U., "The influence of operational parameters on the surface quality of continuously cast slabs", Proceedings of the 4th International Conference Continuous Casting, Verlag Stahleisen mbH, Dusseldorf, 128-141, (1988).

[41] Irving, W.R., Perkins, A., "Basic parameters affecting the quality of continuously cast slabs", In Continuous Casting of Steel, Proceedings of an International Conference, The Metals Society and IRSID, Biarritz, France, 107-115, (1977).

[42] Ueshima, Y., Mizoguchi, S., Matsumiya, T., Kajioka, H., “Analysis of solute distribution in dendrites of carbon steel with $\delta / \gamma$ transformation during solidification", Metall. Mater. Trans. B, 17(4): 845-859, (1986).

[43] Kittaka, S., Uehara, M., Sato, T., Higashi, H., "High speed casting mold for billet caster (NS Hypermold)", Nippon Steel Technical Report, Japan, No:82 (2000).

[44] Li, C., Thomas, B.G., "Maximum casting speed for continuous cast steel billets based on sub-mold bulging computation", Steelmaking Conference Proceedings, Nashville, TN, USA, 109-130, (2002).

[45] Mazumdar, S., Ray, S.K., "Solidification control in continuous casting of steel”, Sadhana, 26(1): 179198, (2001).

[46] Cheung, N., Santos, C.A., Spim, J.A., Garcia, A., "Application of a heuristic search technique for the improvement of spray zones cooling conditions in continuously cast steel billets", Appl. Math. Modell., 30(1): 104-115, (2006).

[47] Irving, W.R., Continuous Casting of Steel 1st Edition, CRC Press, UK, (1993).

[48] Santos, C.A., Garcia, A., Frick, C.R., Spim, J.A., "Evaluation of heat transfer coefficients along the secondary cooling zones in the continuous casting of steel billets", Inverse Prob. Sci. Eng., 14(6): 687$700,(2006)$. 